\title{
Determinants of Decision to Use Herbicides by Smallholder Farmers: The Case of Dale Sadi District Kelem Wolega Zone, Oromia, Ethiopia
}

\author{
Dr. Krishna Naidu ${ }^{1} \quad$ Habtamu Rufe Gurmu ${ }^{2}$ \\ 1.Ambo University College of Agriculture and Veterinary Science, \\ Department of Agribusiness and Value chain management, Ambo, Ethiopia \\ 2.Dambi Dollo University College of Agriculture and Veterinary Medicine Department of Agricultural \\ Economics, Dambi Dollo, Ethiopia
}

\begin{abstract}
The study was conducted in Dale Sadi district Kelem Wolega Zoneof Oromia Regional State. Even if progresses have been seen through time, decision to use improved agricultural technology was found at its low level. Therefore, the study was initiated to identify factors affecting herbicides use decision by smallholder farmers. The typical data used was cross sectional data that were collected from 140 respondents. Primary data was collected by using semi-structured questionnaire and secondary data were collected from articles, journals and others. For analysis of data descriptive statistics such as mean, maximum, minimum and percentage were used and for econometric analysis double hurdle model was employed for analyzing primary data collected by survey questionnaire. The descriptive analysis revealed that $70.71 \%$ of farm households were user of herbicides while the remaining 29.29\% were non user. The result from Econometric analysis revealed that, Sex of household head, education status, total livestock owned and access to credit service has influencing positively and significantly to decision to use and volume of herbicide applied to an hectare of farm land. Whereas, distance of farmers' home from the nearest market influence volume of herbicides applied to hectare of cultivated land negatively and significantly. Therefore, concerning body should focus on promoting training, increasing existing access to credit service and improve market infrastructure that would enhances agricultural technology use to transform agricultural economy and enhance role of improved agricultural technology in economic development.
\end{abstract}

Keywords: Decision to Use, Double Hurdle Model, Smallholder, Technology

DOI: $10.7176 / \mathrm{JESD} / 12-13-02$

Publication date:July $31^{\text {st }} 2021$

\section{INTRODUCTION}

\subsection{Background of the Study}

Development in the agricultural sector has been changed effectively underlining use of modern technologies to increase food production. Hence it increases greater consumption of pesticides and other supplementary agricultural technologies. Technologies play vital role in economic development which consists of introduction of high yielding seeds variety, fertilizers and plant protection measures which contribute to poverty alleviation and grain crops require application of agricultural technology like herbicides, insecticides, fungicides and others. About $83 \%$ of the smallholder farmers lives in rural Ethiopia were tied to traditional agriculture which is not recommended for growth. Change in these technologies enhance agricultural sector productivity per hectare and bring rapid increase in production (Shita et al., 2018).

A pesticide which includes herbicides, insecticides and fungicides has important contribution in production and productivity of agriculture and these pesticides commercially produced compounds that are used for controlling pests, weeds and disease (Rehman et al., 2016). Herbicide is chemical substances used for killing weeds for the purpose of preventing their competition with crops. The use of herbicides is at increasing rate in the world for crop production and has being adopted in developing countries like Ethiopia due to shortage and costy of manual weeding and the need to an increase in crop production (Adhikari et al., 2020). Increased herbicide use promotes efficiency, which leads to increase in production. Herbicide application is normally the most effective and least labor furious weed control strategy with the topmost yield return (Rodenburg et al., 2015). According to (Rehman et al., 2016) farmer is likely to adopt herbicide that leads to offset manual weeding that permits for weeding larger crop fields. Farmers mostly use herbicides and insecticides to control weed and insects respectively, and other disease in cereal crop production. The intensity of technology utilization was a measured in-term of recommendation rate per hectare basis. Although it has been adopted, low use intensity of technology indicates that introduced technology is not effective. Smallholder farmers try to adopt new technologies once or more times and not-adopt due to internal and external factors influencing their decision (Moti et al., 2013). Recently, Adhikari et al. (2020) studied on decision to use herbicides in wheat production by farm household in Nepal, employing probit regression model revealed that education status of household head, farm size, migration and membership to cooperatives positively affect decision to use herbicides. Also they concluded in their finding 
that, use of herbicide increases productivity of wheat, compared with non-users of herbicides.

According to Tamru et al. (2017) in Ethiopia identified that adoption of herbicide is associated with closeness to urban centers, access to all weather roads, and wage rate. Accordingly, Mutale et al. (2017), undertaking study on factors influencing joint adoption of pesticide and conservation technologies in Zambia revealed that members to a cooperative, male-headed household, farm size, receiving advice technologies were positively influencing the joint- adoption of herbicides. Assessment on herbicide rising and its driving forces in China showed that migration, irrigation, farmers' education were positively associated to herbicide use (Huang et al., 2017). The result of truncated model revealed to measure volume of chemical fertilizers applied being male, model farmers, family size, land size, livestock ownership, access to credit, number of extension contact and distance of farmers to input market are determinant's of commercialization of input market as buyer (Chala and Chalchisa, 2017). Intensity use of improved technology adoption is strongly affected by the level of household head's education, available family labor for farming, farm size, farmers' confidence in skills of the extension agents, and access to credit (Moti et al., 2013). According to Beltran et al. (2013), studied on issues that influence the use of agro-chemicals (herbicides) in Philippine on rice farming system found that Family size, Age of household head, irrigation, farm size, input price, assess of credit and source of income were the important factors determining the adoption of herbicide.

\subsection{Statement of the Problem}

Agricultural productivity growth and development in the Sub Saharan Africa is below which required to achieve food security and reduction of poverty goals of the region (Akpan et al., 2012). Obvious constraints against production and productivity by farmers were weeds, pest and soil infertility problem (Eifediyi et al., 2014). As the result, farmers seem to have protected crops against weeds and diseases by using herbicides. Different researchers listed varias factor that are responsible to low production and productivity of agriculture in Ethiopia. Weed is one of the major factors that contribute to a lower production. Losses caused by weeds in agriculture practices depend on the density of weed type, its infestation, and agronomic practices adopted in cultivation. Yield losses also caused through the presence of weeds which may attract other biotic that resulted in yields reduction, such as different diseases and birds that feeds grain (Demont and Rodenburg, 2016). As a result application of herbicides is type of technology that smallholder farmers should follow.

According to Getachew (2016) in Boricha district regarding weed and pest control measures only $6.3 \%$ of the farmers apply herbicide on their farm and $86.7 \%$ of respondents are the maximum pesticides users followed by $52.5 \%$ of Damot Gale district farmers and adopter also apply pesticide at minimum scale. According to Belay (2016), lack of information, technical knowledge, interaction and capacity of local actors contributed to weak agricultural extension system in supporting the smallholder farmers in their pesticide use practices and shortage of developmental agents work with a large number of farmers, limited practical skills in identifying pests and pesticide hinder in pesticide use level. Manual weeding is used to control weed competition with crops, but their cost is rising due to increased labor cost. Therefore, since herbicide essential in developing countries to substitute hand weeding which is traditional and time consuming the need to an increase in crop production and manual protection from insects were too costly (Mutale et al., 2017). Despite an increase in herbicide use in Ethiopia, there was scanty of empirical studies examines the determinants of herbicides decision and, little information is available on factors that determine on intensity use of herbicide. Dale Sadi district was among those which are characterized by low herbicides practices and low productivity seen at most. Consequently, objective of the study was to identify factors affecting decision to use herbicides and estimate intensity use of herbicides by smallholder farmers in the study area. The study also provides use full information for potential users' smallholder farmers, researchers, research centers, development organization, NGOs, input suppliers, buyers, governments and policy makers regarding key factors affecting use level of herbicides.

\section{METHODOLOGY}

\subsection{Description of the Study Area}

The study carried out in Dale Sadi district Kelem Wolega Zone Oromia Regional State and the district is located between $35^{\circ} 06^{\prime} 34.5^{\prime \prime} \mathrm{E}$ and $35^{\circ} 11^{\prime} 15^{\prime \prime} \mathrm{E}$ longitudes and $8^{\circ} 43^{\prime} 35^{\prime \prime} \mathrm{N}$ and $9^{0} 07^{\prime} 15^{\prime \prime} \mathrm{N}$ latitudes; bordered to Southwest by Sadi Canqa District, to West by Dale Wabera district, to North by Lalo Kile district, to East by Ayira district and to South by Ilu Aba Bora Zone. Total population of the district is about 88635 of which $53.36 \%$ were females and $46.64 \%$ were male. The mean temperature of the study area is $25^{\circ} \mathrm{c}$. The district is generally divided to two agro climatic zones from which $60 \%$ is midland and $40 \%$ lowland. The average annual rain fall is about $1200-$ $2350 \mathrm{~mm}$ and elevations ranges between 1200-2200m above sea level [8]. The district also characterized by main economic activities of mixed farming system that is crop and livestock production. The total land of district is about 69418 hectares. The proportion of cultivated land area, grazing land and others land were about $60 \%, 20 \%$ and $20 \%$ respectively from total land the district covers. The major food crops cultivated in the districts are maize, common beans, pigeon peas, finger millet, sorghum and coffee is the major cash crops of the district produced by 
smallholder farmers. Livestock production is another source of income next to crop production. Farmers keep a number of livestock; cattle 85189, poultry 62906, sheep 28600, goats 19699, donkey 3839, mule 470 and horse 181 for different purpose (ARDSAO, 2019).

\subsection{Method of Data Collection, Type and Sources}

For this study both primary and secondary source of data was used to collect both quantitative and qualitative type of data. A data collection tool was semi-structured questionnaire that consists both open ended and closed ended questions using personnel interview. The questionnaire consists demographic, socio-economic, and institutional variables. The questionnaire was refined in the office before implementation of actual survey to in-line with objectives of the study. Interview was conducted by enumerators with diploma and degree holders, who were fluent in local language and trained on the content of questionnaire and interview techniques. Secondary data was collected from Dale Sadi Agricultural Office (DSAO) to get supplementary information related to use of herbicides, Central Statistics Agency (CSA) and Published literature such as books, journals and articles were reviewed.

\subsection{Sampling Procedure and Sample Size}

For the study, a two-stage sampling technique would be used to identify sample households. In the first stage, kebeles in the district were classified into two according to their agro-ecology namely Midland and Lowland. Out of 27 rural kebeles in the district's 16 kebeles were found in midland and 11 kebeles found in lowland. From midland agro-ecology 2 kebeles, namely Arere Ogiyo and Gonsi Dereba were selected randomly and one kebele Cammoo was selected from lowland by using $10 \%$ probability level. Secondly, from total of three kebeles, a total of 140 smallholder farmers were selected randomly using probability proportional to sample size (see table 1). Table 1: Sampling kebeles and representative sample households

\begin{tabular}{|c|c|c|c|c|c|c|}
\hline \multirow[b]{2}{*}{$\begin{array}{l}\text { Name } \\
\text { of } \\
\text { district }\end{array}$} & \multirow[b]{2}{*}{$\begin{array}{l}\text { Category of } \\
\text { agro-ecology }\end{array}$} & \multicolumn{5}{|c|}{ Sampled kebeles based on $10 \%$ probability level } \\
\hline & & $\begin{array}{l}\text { Total rural } \\
\text { kebels in agro- } \\
\text { ecology }\end{array}$ & $\begin{array}{l}\text { number of } \\
\text { kebeles } \\
\text { selected }\end{array}$ & Name of kebeles & $\begin{array}{l}\text { Total hhs } \\
\text { of } \\
\text { Kebeles }\end{array}$ & $\begin{array}{l}\text { Sample } \\
\text { size using } \\
\text { pps }\end{array}$ \\
\hline \multirow{3}{*}{$\begin{array}{l}\text { Dale } \\
\text { Sadi }\end{array}$} & \multirow{2}{*}{ Mid land } & \multirow[t]{2}{*}{ 年 } & \multirow{2}{*}{2} & Arere Ogiyo & 480 & 54 \\
\hline & & & & Gonsi Dereba & 320 & 42 \\
\hline & Low land & 11 & 1 & Cammo & 360 & 44 \\
\hline & Total & 27 & 3 & & 1160 & 140 \\
\hline
\end{tabular}

Sources: Own computation, 2020

Additionally, total sample size for sample household determination was made by Cochran (1997), formula because of heterogeneity of sample respondents which is given by:

$\mathrm{N}=\frac{\mathrm{Z}^{2} \mathrm{pq}}{\mathrm{e}^{2}}$

Where, $\mathrm{N}=$ is the sample size,

$\mathrm{Z}=$ is the value standard deviation at desired confidence level and curve is $95 \% \mathrm{Z} \frac{\alpha}{2}=1.96 \mathrm{p}=$ proportion of population to be included in sample $(0.1)$, $\mathrm{q}=1-\mathrm{p}, \mathrm{q}=0.9, e=$ precision rate or accepted error for the study $5 \%$ Cochran (1997). $\mathrm{N}=\frac{1.96^{2}(0.1)(0.9)}{(0.05)^{2}}=138.29$. Alternative system of sample calculation for different model has been suggested by Green (1991) as: $n \geq 50+8 p$ where $p$ is the number of predictors (explanatory variables) and $n=$ sample size, Using above method a sample of $n \geq 50+8 \times 11 \geq 140$ participants should be selected for this study and sample of 140 could be sufficient (Green, 1991).

\subsection{Method of Data Analysis}

\subsubsection{Descriptive analysis}

Descriptive statistics such as percentages, mean, minimum, and maximum were used in the process of examining the explanatory variables. Moreover, t-test and $\chi^{2}$-test were used to test whether there were significant differences between household's herbicides use level in terms of continuous and categorical variables, respectively.

\subsubsection{Econometric analysis}

The econometric model for this analysis is a double hurdle model because of sequential decision made by the households. Commonly used model for limited dependent variables are Tobit, Heckman's selection models and Double hurdle models (Verbeek, 2017). Different studies employed double hurdle models in order to identify factors that determine adoption and intensity use (Martey et al., 2013; Leta, 2018; Adhikari et al., 2020). As, explained in Cragg (1971), zero values may be observed due to decision of an individual. In our concern probit model was estimating the probability of adopting pesticides as function of some socio-economic variables and it estimate quantity used. Therefore, when we have some zero observation, we should not use Tobit model. The Tobit 
model is applicable only in those cases when the latent variables can take negative values, because it assumes the observed zero values are consequence of censoring and non-observablity. The Heckit and DHM are similar in identifying rule of deciding the discrete (zero or positive) outcomes. Both models accept that outcomes are determined by level of adoption. However, heckit as opposed to DH assume there is no zero observation in the second once the first-stage selection is passed. On the other hand, the double-hurdle model assumes that zero values can be reported in both stages (Heckman, 1979). The double hurdle model first estimates a probit model for adoption decision then in the second step it uses truncated regression to estimate the level of use (Wooldridge, 2012). Double hurdle model assumes two hurdles to observe values. In the first stage probit model was used to estimate determinants of adoption, and in the second stage truncated was used to estimate quantity of herbicides used. Cragg's model for determining adoption decision and volume of use was common in agricultural economic literature. Thus, the first hurdle estimates the decision to adoption or not and conditioned to adoption decision second stage estimate volume of herbicides used by smallholder farmers. The second stage of double hurdle model use truncated regression model to determine the extent of pesticides use level which depend on latent variable $\left(\mathrm{Y}^{*}\right)$ being greater than zero which means conditioned to adoption decision. Therefore, for this study probit regression model and truncated regression model were used to analyze level of herbicides used by smallholder farmers. The formula of the first hurdles or adoption decision equation was estimated with a normal probit model following (Wooldrige, 2012; Verbeek, 2017).

An econometric model is specified as:

$$
\begin{aligned}
& \mathrm{Y}_{1}^{*}=\beta_{1} \mathrm{X}_{1 \mathrm{i}}+\varepsilon_{1 \mathrm{i}} \\
& \mathrm{Y}^{*}{ }_{1}=\left\{\begin{array}{l}
1 \text { if smallholder farmers adopted to pesticides; } \mathrm{Y}^{*}>0 \\
0 \text { if } \mathrm{Y}^{*} \leq 0 \text { otherwise }
\end{array}\right.
\end{aligned}
$$

Where, $Y_{1}^{*}$ is a latent (unobserved) dependent variable that indicate binary decision to adopt to pesticides take one if adopt and zero otherwise; $X_{1 i}$ Represent explanatory variables hypothesized to affect adoption of pesticides, $\beta_{1}$ Show vector of parameter to be estimated and $\varepsilon_{1 \mathrm{i}}$ represent standard error terms. Second stage of double hurdle model, truncated regression model given below following (Wooldridge, 2012) to estimate factors that affect level of herbicides used:-

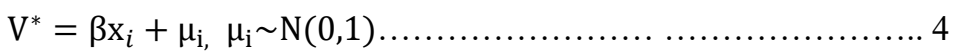

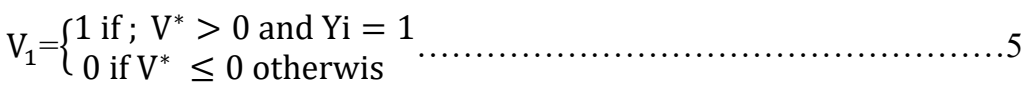

Where: Vi will be volume of pesticides used which depends on latent variable $Y i^{*}$ being greater than zero and conditional to the decision to adopt $Y_{1}=1, \mathrm{~V}^{*}$ is latent variable describing farmers decision on level of adoption and $\beta$ is vector of parameter to be estimated (Wooldridge, 2012). Prior to run econometric model, hypothesized independent variables should be checked for existence of multicolinearity problem. For checking existence of multicollinearity problem between explanatory variables two measures were suggested. These are Variance Inflation Factors (VIF) for correlation among continuous explanatory variables and contingency coefficient was used to test multicollinearity problem among dummy independent variables (Maddala,1992).

\subsection{Variables Definition and Working Hypothesis 2.5.1. Dependent variables}

Decision to Use Herbicides (DUH): - This is dummy dependent variable that represents the probability households to use herbicides regressed in first hurdle model procedure, given socio-economic, demographic and institutional factors. It refers use ' 1 'otherwise ' 0 '.

Volume of herbicides used (VHU): - It was Continuous variable regressed by truncated regression model and represent amount of herbicides used by households during 2019/2020 farming season measured in litter.

\subsubsection{Independent variables}

Independent variable in this study was variables which thought to have influence on decision to use herbicides and intensity of use. Thus the explanatory variables which are expected to have correlation with dependent variables are hypothesized as follows (see table 2): 
Table 2: Summary of variables description and Hypothesis

\begin{tabular}{|c|c|c|c|c|c|c|}
\hline $\begin{array}{l}\text { Variable } \\
\text { code }\end{array}$ & Description & Type & Measurement & $\begin{array}{l}\text { Expec } \\
\text { to } \mathrm{d} \\
\text { variab }\end{array}$ & $\begin{array}{l}\text { ed sign } \\
\text { pendent } \\
\text { es }\end{array}$ & $\begin{array}{l}\text { Supportive } \\
\text { studies }\end{array}$ \\
\hline DUH & $\begin{array}{l}\text { Dependent variable indicating } \\
\text { decision to use herbicides }\end{array}$ & $\begin{array}{l}\text { Dummy } \\
\text { dependent }\end{array}$ & $1=$ yes, $0=$ no & DUH & VHU & \\
\hline VHU & $\begin{array}{l}\text { Volume of herbicide used per } \\
\text { hectare }\end{array}$ & $\begin{array}{l}\text { Continuous } \\
\text { dependent }\end{array}$ & $\begin{array}{l}\text { Littre per } \\
\text { hectare }\end{array}$ & & & \\
\hline SEXHH & Sex of the household head & Dummy & $\begin{array}{l}1=\text { male } \\
\text { otherwise }=0\end{array}$ & - & - & {$[21]$} \\
\hline EDUSHH & Education status of household head & Continuous & $\begin{array}{ll}\text { Year } & \text { of } \\
\text { formal } & \\
\text { schooling } & \\
\end{array}$ & + & + & {$[13]$} \\
\hline FASHH & Family size of household head & Continuous & Number & - & - & {$[18]$} \\
\hline FARMSI & Farm size household head owned & Continuous & Hectare & + & + & $\begin{array}{l}{[4,28,33,} \\
34]\end{array}$ \\
\hline TLIVO & Total livestock owned by household & Continuous & TLU & + & + & {$[23,29]$} \\
\hline DMARK & $\begin{array}{l}\text { Distance from the nearest market in } \\
\text { hour }\end{array}$ & Continuous & $\begin{array}{l}\text { Walking } \\
\text { hour }\end{array}$ & - & - & {$[35]$} \\
\hline ACRED & Household access to credit service & Continuous & $1=$ yes, $0=$ no & + & + & {$[32,33]$} \\
\hline VLSHH & $\begin{array}{l}\text { Village level status of household } \\
\text { head }\end{array}$ & Dummy & $1=$ yes, $0=$ no & + & + & {$[13]$} \\
\hline ACCMI & Access to market information & Dummy & $1=$ yes, $0=$ no & + & + & {$[1,35]$} \\
\hline FAREX & $\begin{array}{l}\text { Years of farmers experience in use } \\
\text { of pesticides }\end{array}$ & Continuous & $\begin{array}{l}\text { Number of } \\
\text { years }\end{array}$ & + & + & {$[7]$} \\
\hline OFINCO & $\begin{array}{l}\text { Annual earnings of household from } \\
\text { off-farm income activities. }\end{array}$ & Dummy & $1=$ yes, $0=$ no & + & + & $\begin{array}{l}{[12, \quad 23,} \\
33]\end{array}$ \\
\hline
\end{tabular}

\section{Result and Discussion}

Under this section descriptive and econometric analysis of data collected on determinants of decision to use herbicides were presented. The descriptive statistics result was presented in mean and standard deviation analysis of explanatory variables. Subsequently, the econometric result were presented by the marginal effects of explanatory variables showing the probability of use of herbicides by smallholder farmers associated with a one unit increase for continuous variables and being in the success category for dummy variables.

\subsection{Proportion of Sampled Households}

Out of total interviewed 140 households $99(70.71 \%)$ of them were user of herbicides while the remaining $41(29.29 \%)$ were not. (table 3 ).

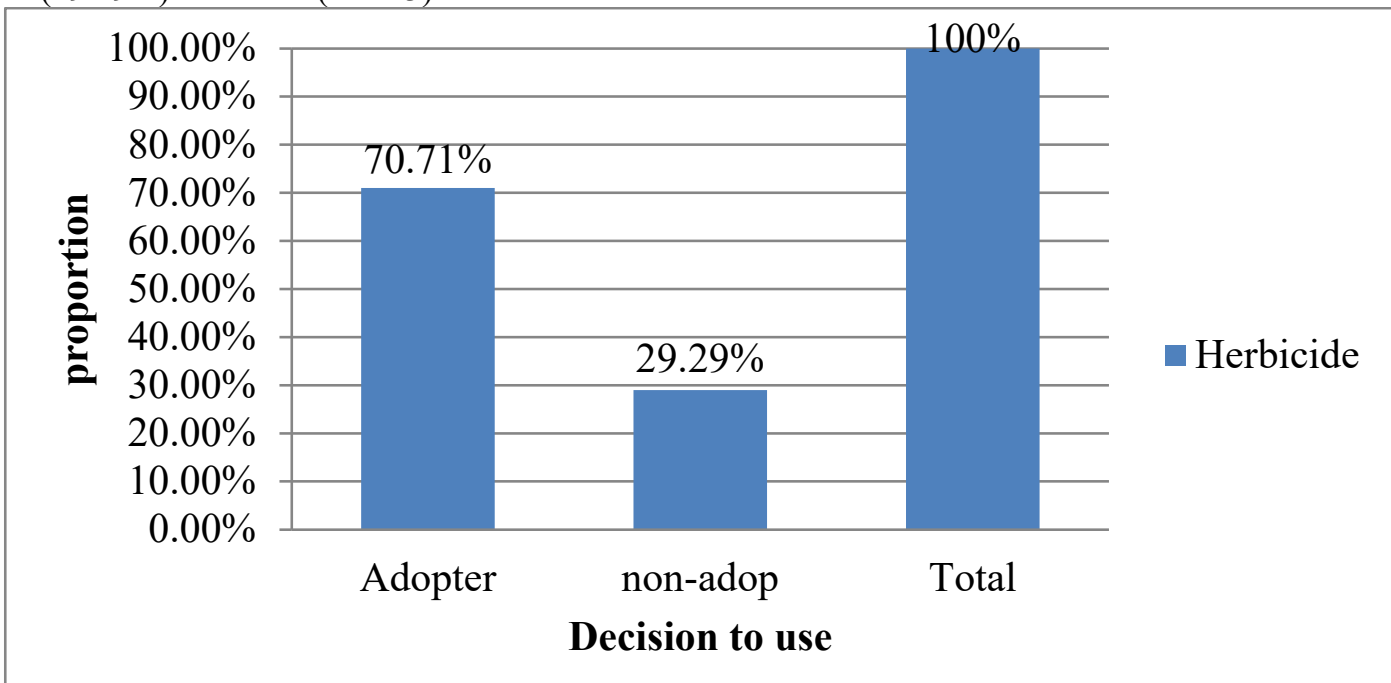

Figure 3: Bar graph of user and non-user of herbicide Source: Own survey result (2020) 


\subsubsection{Demographic Characteristics}

Regarding adoption 9(6.5\%) female-headed and 90(64.5\%) male-headed households were users and the remaining $3(2.17 \%)$ female headed and 38(26.81\%) male-headed households were non-user of herbicides. Education status of household head influence decision to use of newly introduced agricultural technologies positively. According to the survey result described in below table the mean education level of sampled farmers was about 6.52 years of formal schooling. The average education level of adopters of pesticides was about 8.12 and while that of nonadopters have 2.61. The statistical test $(\mathrm{t}=-11.87)$ show the existence of a significant mean difference between user and non-user of herbicides and found to be significant at $1 \%$ probability level. Hence, educated farmers would be more aware of the benefits of modern technologies and may have a greater ability to learn new information. On the other hand, family size of the household might have dual purpose in which, it provides more family labor which tends to reduce herbicides use. Average family size included in the sample was about 5.75 family members and the mean family size user and no-user of herbicides is 5.71 and 5.82 respectively. The $t$-test $(t=-0.32)$ indicated that non-significant mean difference between user and non-user in terms of family size. Farmer experience in use of chemical pesticides is also another household factor that affects adoption of pesticides. The average years of farmers experience in use of chemical pesticides in the study area is about 4.23 years. The mean year experience of farmer for user and non-user of herbicide is about 4.80 and 2.88 years respectively. The $t$-value $(t=-3.74)$ of inferential statistics show statistical mean difference of farmers experience in use of pesticides at $1 \%$ probability level (table 3).

\subsubsection{Socio-economic factors}

Since agricultural technology require land to adopt, farm size influence household decision to accept or reject agricultural technology. The average total farm size of smallholder farmers included in the sample was about 2.27 hectare. The mean farm size owned by user and non-user of pesticides in the study area were about 2.41 and 1.94 hectare respectively. The $\mathrm{t}$-value $(\mathrm{t}=-2.19)$ show that there was significant difference between user and non-user at 5\% probability level. Similarly, livestock is important asset for households to supplement income shortage by farm households. Farm households mitigate credit demand through sell of live animals and their product. Those farm households who adopt herbicides has mean TLU value of 5.72 and while non-adopters have 1.77 . This result show there is difference with statistical analysis of TLU shows $t$-value $(t=-3.29)$ indicate that statistically significant at $1 \%$ probability level. On the other hand, market information plays great role to adopt new technologies, reduce risk and uncertainties for smallholder farmers. Majority of respondent reported accessed market information through informal means of extension workers and traders to purchase pesticides. The $\chi^{2}-$ test Showed that there is a proportion difference between adopters and no-adopters in-terms of access to market information with $\left(x^{2}=4.19\right)$ and significant at $5 \%$ probability level (see table 3 ).

\subsubsection{Institutional and infrastructural factors}

Distance of smallholder farmers from the nearest market was continuous variable measured in hours. Survey result show that mean distance of households from the nearest market was about 2.49 hours. The mean nearest distant of market from adopters and non-adopters of pesticides was about 2.29 and 3.00 hours respectively. Therefore, time taken to travel from home to nearest market was important factors that affect adoption of agricultural technology and farmers nearest to market may easily get required product on time. The result from inferential $\mathrm{t}$-value $(\mathrm{t}=2.41)$ indicate that there is statistical difference between adopters and non-adopters of pesticides at 5\% probability level. Credit is also an influential institutional factors used to solve finance problem of farmers who cannot afford to purchase input from own income and saving. From sampled households 78(55.71\%) having access to credit and about $62(44.29 \%)$ respondents were reported lacks of access to credit. Results of chi-square value $(\chi 2=44.51)$ indicate that there is statistical difference between user and non-user of herbicides at $1 \%$ probability level (table 3). 
Table 3: Summary of Descriptive Statistics

\begin{tabular}{|c|c|c|c|c|c|c|c|c|c|}
\hline \multirow{2}{*}{$\begin{array}{l}(\mathrm{N}=140) \\
\text { Variables }\end{array}$} & \multicolumn{2}{|c|}{$\begin{array}{c}\text { user of } \\
\text { herbicides } \\
(\mathrm{n}=99)\end{array}$} & \multicolumn{2}{|c|}{$\begin{array}{l}\text { non- user of herbicides } \\
\qquad \mathrm{n}=41\end{array}$} & \multicolumn{4}{|c|}{$\begin{array}{c}\text { Total } \\
(\mathrm{n}=140) \\
\end{array}$} & \multirow[t]{2}{*}{ ttest $/ \chi^{2}$} \\
\hline & Mean & $\begin{array}{l}\text { Std. } \\
\text { Dev. }\end{array}$ & Mean & Std. Dev. & Mean & $\begin{array}{l}\text { Std. } \\
\text { Dev. }\end{array}$ & Min & Max & \\
\hline \multicolumn{10}{|l|}{ Continous } \\
\hline VHU/He & & & & & 0.51 & 0.41 & 0 & 1 & \\
\hline EDUSHH & 8.12 & 2.52 & 2.61 & 2.44 & 6.51 & 3.55 & 0 & 13 & $-11.87^{* * *}$ \\
\hline FAMSI & 5.72 & 1.83 & 5.83 & 2.09 & 5.75 & 1.9 & 2 & 12 & $0.31 / \mathrm{NS}$ \\
\hline FARSI & 2.41 & 1.14 & 1.94 & 1.22 & 2.28 & 2.08 & 1.18 & 6 & $-2.19^{* *}$ \\
\hline TLIVO & 5.14 & 3.07 & 3.33 & 2.68 & 4.61 & 3.06 & 0 & 13.52 & $-3.29^{* * *}$ \\
\hline DMARK & 2.11 & 1.5 & 3.01 & 1.9 & 2.52 & 2.75 & 0.5 & 6.5 & $2.40^{* * *}$ \\
\hline FAREX & 4.79 & 2.63 & 2.88 & 3.05 & 4.23 & 2.88 & 0 & 12 & $-3.74^{* * *}$ \\
\hline \multicolumn{10}{|l|}{ Dummy } \\
\hline SEXHH & 0.92 & 0.28 & 0.9 & 0.3 & 0.92 & 0.27 & 0 & 1 & $0.71 / \mathrm{NS}$ \\
\hline ACRED & 0.86 & 0.35 & 0.18 & 0.38 & 0.55 & 0.49 & 0 & 1 & $45.50 * * *$ \\
\hline ACCMI & 0.96 & 0.2 & 0.48 & 0.51 & 0.85 & 0.35 & 0 & 1 & $4.19 * *$ \\
\hline VISHH & 0.86 & 0.35 & 0.18 & 0.38 & 0.49 & 0.54 & 0 & 1 & $1.81 / \mathrm{NS}$ \\
\hline OFINCO & 0.96 & 0.2 & 0.48 & 0.51 & 0.28 & 0.45 & 0 & 1 & $0.01 / \mathrm{NS}$ \\
\hline
\end{tabular}

Source: Own survey result, $(2020)$

$* * *, * *$ and $*$ represent $1 \%, 5 \%$ and $10 \%$ significance level respectively

$\chi^{2}=$ test for dummy variables

$\mathrm{t}$-value $=$ test for continuous variables

\subsection{Econometric Model Result}

Under this sub-section, the result of Double hurdle regression models presented. The results of DHM for factor affecting herbicides use displayed below in table 4. Pseudo $\mathrm{R}^{2}$ value indicates that the independent variables included in the model explain 0.679 variations in the likelihood to adoption of pesticides. The Wald chi-square value's was 45.02 significant at $1 \%$ probability level indicating that explanatory variables explain the probability to adoption and use level respectively. The analysis of survey data was carried out by STATA version 15.0. Multicollineraty test was conducted and found no serious multicolenearty among the independent variable indicated by mean VIF of 1.34 which is less than 10 (see appndex table 1 and 2). In addition, to mitigate the problem of heteroscedasticty calibrating robust standard error was used. Breusch-Pagan / Cook-Weisberg test for heteroscedasticity test also shows there was no problem of hereroscedasticity.

\subsubsection{Determinants of factors affecting adoption of pesticides.}

Factors affecting decision to use herbicide was estimated by maximum likelihood method using double hurdle model. Out of 10 explanatory variables included in the model, four were found to be significant to decision to use. These variables were education status of household, access to credit, total livestock owned and distance to the nearest market.

Education status of household head: Education influences the likelihood positively and significantly. This may be due to educated households have more knowledge than less educated one. The marginal effect of variable education was 0.058 indicated that a unit increase in formal grade increases the probability of use to herbicides by $5.8 \%$ and significant at $1 \%$ probability level (table 4 ). Hence, education has the power to change the knowledge, skill and attitude of farmers. The result is consistent with the finding of (Moti et al., 2013; Abebe, 2018) they stated that farmers with high level of education adopt new technologies easily and use them effectively. Currently, (Adhikari et al., 2020) investigated that education has a significant positive influence on adoption of agricultural technologies.

Total Number of livestock owned in TLU (TLIVO): Result of probit model show that total livestock owned by household had positive and significant effect to decision to use herbicides. Result in below table 5 shows increase in one TLU resulted to increase the likelihood of use of herbicide by $1.9 \%$ and significant at $10 \%$ probability level (table 4). The positive sign indicated farmers with higher number of TLU could have higher chance to buy herbicide than fewer owners because livestock and livestock product may be used as source of income to afford cost of input. Leake and Adam (2015) reported that being owner of more livestock increases the level of adoption of improved agricultural technology. However, result of the study contradicts current finding of Guye and Sori (2020) that tropical livestock unit affects adoption of malt barley technology package by farmers negatively.

Distance from the nearest market: Distance from nearest market had been negatively and significantly influence the likelihood of decision to use herbicide by smallholder farmers at $10 \%$ probability level. Keeping other factors 
held constant. Increases in an hour to reach nearest market affect decision to use herbicide by $0.04 \%$ (table 4 ). This may be due to the fact that the further the market distance increased; the more it increases transportation costs and opportunity cost of time. According to Leta, 2018), found that market distance to input and output center is negatively and significantly influence probability of participation and intensity. According to Afework and Lemma (2015) revealed that farmers living near the market would easily access market for their farm produce hence readily adopt and intensively use new technology.

Access to Credit: Result in below table 4 revealed that access to credit found to be positively and significantly influences the likelihood of herbicide decision to use at $1 \%$ probability level. Holding other factors constant, shift from lack of credit to access to credit has increased the probability of using herbicide by $0.27 \%$. It implies that access to credit solve farm households economic problem to adopt technology. The result also agree with [17] which state that credit use was found to have positive and significant influence to probability of adoption and intensity use of wheat row planting.

Table 4: Probit and truncated estimation result of decision to use herbicide

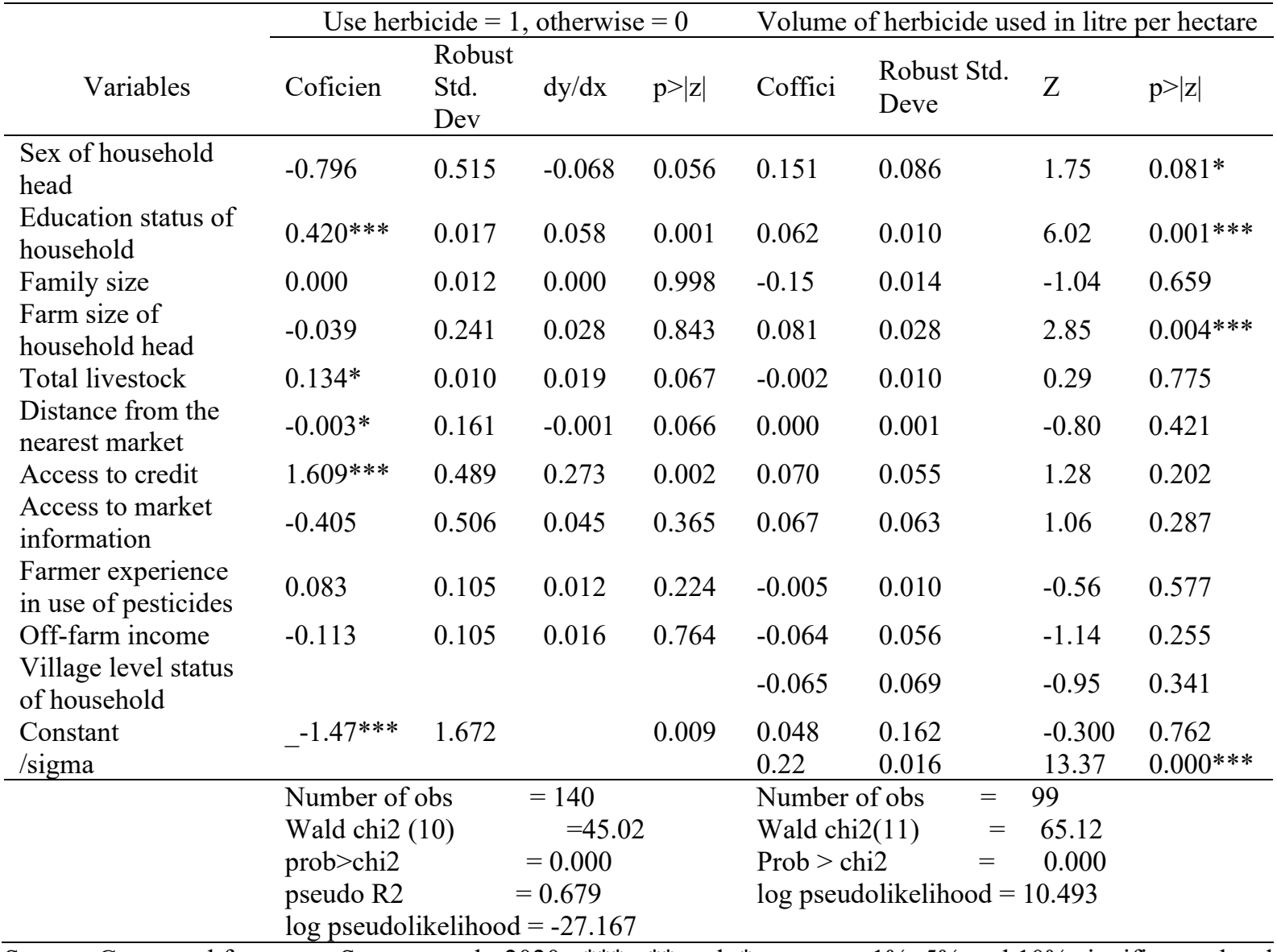

Source: Computed from own Survey result, 2020, ***,** and * represent $1 \%, 5 \%$ and $10 \%$ significance level respectively

\subsubsection{Determinants to estimate level of pesticides use.}

Factors that affect intensity use of herbicide were analyzed separately. Thus herbicide used by smallholder farmers is summed in measurement of litter. The overall goodness of fit of the model indicated as wald chi2 $(11)=65.12$. The null hypothesis for the test is that all coefficients is zero (prob $>$ chi $2=000)$. Model chi-square test applying degree of freedom was statistically significant at $1 \%$ significance level indicating that the goodness of fit for the second hurdles. The estimation result also indicated that levels of herbicide used were associated significantly with three explanatory variables. Those variables are sex, education status and farm size owned by household head.

Sex of household head: Sex is dummy variable which found to be positively affecting herbicide use level. This means that male headed households used 0.151 littre more volume of herbicide per hectare when compared to the female headed counterparts and significant at 10\% significance level (table 4 ). This means males has an advantage to obtain knowledge of pesticides and travelling long distances' to access the market for purchase relative to female headed households. In-line with finding of Donkoh et al. (2019), found that being male-household head positive and significantly influence the adoption of improved agricultural technologies.

Education status of household: Education status of farm households had positively affect volume of herbicide use. Increase in one year of formal schooling increases level of pesticides use on average by 0.062 littre and 
significant at $1 \%$ significance level (table 4). The result is consistent with finding of Dinku and Beyene (2019), in that education had positively and significantly influence adoption and intensity of wheat row planting. Similarly, educational status of the household head has a positive effect on the status, intensity and speed of technology adoption (Afework and Lemma, 2015).

Farm size of household head: Farm size in hectares influence level of herbicide use positively and significantly at $1 \%$ significance level. Accordingly, an increase in one hectare of farm size increase level pesticides use on average by 0.081 litre (table 4). The result implies farmers who have more land to cultivate may have increase area covered by herbicide to control weeds. The study also agrees with Idrisa et al. (2012), in that they revealed positive and significant relationship between size of farm holding and the extent of use of improved soybean seed in Nigeria. But, the result contradicts with finding of (Donkoh et al. (2019), revealed that farm size was significantly and negatively related with adoption of technologies.

\section{Summary, Conclusion and Recommendations}

\subsection{Summary and Conclusion}

Use of herbicides was found to be important elements of agricultural technology in the study area. The study was designed to analyze factors that determine decision to use and quantity of herbicides used in the district. Specific objectives of the study were to identify factors affecting decision use and to estimate quantity of herbicides used by households in the study area. A total of 140 households were selected randomly using probability proportional to sample size. The analysis was made using descriptive statistics and econometric model to analyzing collected data.

Double hurdle model was used to determine factors affecting decision of farmers and of volume used by sample households. variables expected to be relevant to meet the objectives are Sex, education status, farm size, family size, tropical livestock unit, distance from the nearest market, access to credit, access to market information, Village level status of household head, farmers experiences in use of chemical pesticides and off-farm income.

Out of 140 respondents $99(71.01 \%)$ and $41(28.99 \%)$ farmers were adopter and non-adopters of herbicides respectively. From sample respondents about 12(8.7\%) female headed and $126(91.3 \%)$ were male-headed household. Among explanatory variables included in the model education status, family size, farmer's experience, access to market information, access to credit, distance to the nearest market and farm size were statistically significant.

Result from first stage of DHM show that, One year increase in formal schooling increases the probability to use herbicides positively and significantly at $1 \%$ probability level. Likewise, total livestock owned by household head also positively affect decision to use herbicides and significant at $10 \%$ probability level and access to credit service, were associated to use of herbicide positively and significant at $1 \%$ probability level. Whereas distance from the nearest market influence decision to use herbicide negatively and significant at $10 \%$ probability level.

Sex of household head influence volume of herbicide used positively and significant at $10 \%$ significance level. One year increase in education status increase level of herbicide used on average by 0.062 litre and significant at $1 \%$ significance level. Accordingly, an increase in one hectare of farm size increase quantity of herbicides used on average by 0.081 litre and significant at $1 \%$ significance level. The findings of this research help agricultural bureau, NGOs and input suppliers in identifying the major factors that determine decision to use certain technology and use level of agricultural technology in the study area and recommend that bringing technologies closer to farmers might increase the likelihood of decision to use, thereby increase production and productivity of smallholder farmers to alleviate poverty and promote food security.

\subsection{Recommendation}

The following recommendations are drawn based on finding of the study:

Sex has a significant positive influence to volume of herbicide applied to farm. To increase and motivate the likelihood of adopting modern agricultural technologies by smallholder farmers, policy makers should initiated female headed households to increase the role of gender in agricultural transformation.

Education had significantly positive association to decision to use and quantity of herbicide used. In this regard, the regional and local government needs to strength the existing provision of formal education by facilitating all necessary material. Also all concerned body should influence farmer's awareness to adoption of modern technology thereby increase production and productivity which leads to alleviate poverty at rural farm household in general and particularly to the study area.

Concerned body should concerning development of market infrastructure such as building market places and improving road to reduce transportation costs, thereby made product available around their home which would increase the probability of using technology by smallholder farmers.

The result of the study also recommended that additional financial sources of credit service should be provided by government policy with easy access to compliment the on-going technology adoption.

Generally, brings technologies closer to farmers, thereby reducing the risks that farmers encounter. Farmers 
should be given more and easy access to credit, and need to link farmers to formal sources of credit given its importance in the use of improved agricultural technologies.

\section{REFERENCES}

[1] Abate GT, Rashid S, Borzaga C, and Getnet K, 2016. Rural finance and agricultural technology adoption in Ethiopia: does the institutional design of lending organizations matter? World Development, 84, 235-253.

[2] Abebe GG, 2018. Determinants of Adoption of Improved Soybean Varieties: The Case Of Chewaka And Gobusayo Districts, Buno Bedele And East Wollega Zones Of Oromia Region, Ethiopia. MSc thesis. Haramaya Universtiy

[3] Adhikari SP, Yuga N G, Sanjiv S, and Hema KP, 2020. "Decision to Use Herbicide in Wheat Production by the Farm Households in Nepal : A Probit Regression Analysis." 3: 12-19.

[4] Admassie A and Ayele G, 2010. Adoption of Improved Technology in Ethiopia. Ethiopian Journal of Economics, 19(1), 155-180.

[5] Afework H and Lemma Z, 2015. Determinants of improved rice varieties Adoption in Fogera District of Ethiopia. Science, Technology and Arts Research Journal, 4(1): 221-228.

[6] Akpan SB, Nkanta VS, and Essien UA, 2012. A Double-Hurdle Model of Fertilizer Adoption and Optimum Use among Farmers in Southern Nigeria. Tropicultura, 30(4).

[7] Aman T and Tewodros T, 2016. Determinants of Improved Barley Adoption Intensity in Malga District of Sidama Zone, Ethiopia. International Journal of Agricultural Economics. Vol. 1, No. 3, 2016, pp. 78-83. doi: 10.11648/j.ijae.20160103.15

[8] Annual Report of Dale Sadi agricultural office (ARDSAO), 2019.

[9] Belay TM, 2016. Policy-Practice Nexus: Pesticide Registration, Distribution and use in Ethiopia. SM Journal Environ Toxicol, 2(1), 1-13

[10] Beltran J, White B, Burton M, Doole G, and Pannell D, 2013. Determinants of herbicide use in rice production in the Philippines, Agricultural Economics, 44(1), 4555.https://doi.org/10.1111/j.1574-0862. 2012.00631.

[11] Berihun K.H, Bihon kA and Kibrom AW, 2014. Adoption and Impact of Agricultural Technologies on Farm Income: Evidence From Southern Tigray, Northern Ethiopia. International Journal of Food and Agricultural Economics, 91-106.

[12] Chala H and Chalchisa F, 2017. Determinants of Input Commercialization as Buyers of Agro-Chemicals and Improved Seed: Evidence from Farm Households' of Ambo and Toke Kutaye Districts, West Shewa Zone, Ethiopia. AMERICAN RESEARCH JOURNAL OF AGRICULTURE, PP:1-14

[13] Cochran L, 1997. Career Counseling: A narrative approach. Sage publications.

[14] Cragg J, 1971. Some Statistical Models for Limited Dependent Variables with Application to the Demand for Durable Goods. Econometrical, 39 (5), 829-844.

[15] CSA (Central statics Agency), 2017. Agricultural sample survey 2016/2017 on livestock and livestock characteristics. Central Statistics Authority. Addis Ababa, Ethiopia

[16] Demont M, and Rodenburg J, 2016. On the interaction between weedand bird damage in rice. Weed Research, 56, 193-197. https://doi.org/10.1111/wre.12206.

[17] Dinku A, and Beyene F, 2019. Adoption determinants of row planting for wheat production in Munesa District of Oromia Region, Ethiopia. J. Agric. Ext. Rural. Dev., 11(2), 25-34.

[18] Donkoh SA, Azumah SB, and Awuni JA, 2019. Adoption of improved agricultural technologies among rice farmers in Ghana: a multivariate probit approach. Ghana Journal of Development Studies, 16(1), 46-67.

[19] Eifediyi EF, Omondan GO, Takim FO, and Animashaun J, 2014. An Assessment of the use of agrochemicals among small-scale farmers in Esanland, Nigeria. Niger journal of crop Science [Internet], 2(1), 9-13.

[20] Gebregziabher G, Giordano M, Langan J and Namara R, 2014. Economic Analysis of Factors Influencing Adoption of Motor Pumps in Ethiopia. Journal of Development and Agricultural Economics, 6(12), 490-500.

[21] Getachew D, 2016. Analysis of Preference for Adoption Of Legume Technology Packages: The Case of Chick Pea and Common Bean Producing Smallholder Farmers in Boricha and Damot Gale District, Southern Region.

[22] Gideon DA, Lloyd JS and Baiyegunhi, 2017. Adoption of agrochemical management practices among smallholder cocoa farmers in Ghana, African Journal of Science, Technology, Innovation and Development, 9(6), 717-728, DOI: 10.1080/20421338.2017.1380358

[23] Green SB, 1991. How many subjects does it take to do a regression analysis? Multivariate behavioral research, 499-510

[24] Guye A and Sori O, 2020. Factors Affecting Adoption and its Intensity of Malt Barley Technology Package in Malga Woreda Southern Ethiopia. Journal of Agricultural Economics and Rural Development: Vol. 6(1), pp. 697-704.

[25] Heckman J, 1979. "Sample Selection Bias as a Specification Error,” Econometrica, 47:1 (153-161).

[26] Huang J, Wang S, and Xiao Z, 2017. Rising herbicides use ad its driving forces in China. The European Journal of Development Research, 29, 614-627. doi:10.1057/s41287017-0081-8 
[27] Idrisa YL, Ogunbameru BO, and Madukwe MC, 2012. Logit and Tobit analyses of the determinants of likelihood of adoption and extent of adoption of improved soybean seed in Borno State, Nigeria. Greener Journal of Agricultural Sciences, 2(2), 37-45.

[28] Leake GS and Adam B, 2015. Factors determining allocation of land for improved wheat variety by smallholder farmers of northern Ethiopia. Journal of Development and Agricultural Economics, 7(3): 105112.

[29] Leta A, 2018. Value Chain Analysis of Sheep: The case of Tiyo District of Arsi Zone, Oromia National Regional State, Ethiopia. A Thesis Submitted to School of Agricultural Economics and Agribusiness: HARAMAYA UNIVERSITY

[30] Maddala GS, 1992. Introduction to Econometrics. Second Edition, John Wiley.

[31] Martey E, Wiredu AN, Etwire PM, Fosu M, Buah SJ, Bidzakin J and Kusi F, 2014. Fertilizer adoption and use intensity among smallholder farmers in Northern Ghana: A case study of the AGRA soil health project. Sustainable Agriculture Research, 3(526-2016-37782).

[32] Merga C and Urgesa T, 2014. Determinants and impacts of modern agricultural technology adoption in west Wollega: the case of Gulliso district. Journal of Biology, Agriculture and Healthcare, 4(20), 63-77.

[33] Moti J, Chilot, Y, Menale K, Hugo de G, and Bekele S, 2013. Knowledge, adoption and use intensity of improved maize technologies in Ethiopia (No. 309-2016-5268).

[34] Mutale G, Kalinda T, and Kuntashula E, 2017. Factors Affecting the Joint Adoption of Herbicides and Conservation Tillage Technologies among Smallholder Farmers in Zambia, Journal of Agricultural Science, 9 (12).

[35] Rehman A, Jingdong L, Khatoon R, and Hussian I, 2016. Modern Agricultural Technology Adoption its Importance, Role and Usage for the Improvement of Agriculture. American-Eurasian Journal of Agriculture and Environmental Science, 16 (2), 284-288. DOI: 10.5829/idosi.aejaes.2016.16.2.12840

[36] Rodenburg J, Saito K, Irakiza R, Makokha DW, Onyuka EA, and Senthilkumar K, 2015. Labor-saving weed technologies for lowlandrice farmers in sub-Saharan Africa. Weed Technology, 29(4),751-757. https://doi.org/10.1614/WT-D-15-00016.1.

[37] Samuel D, Efrem A, Beza E and Misganaw A, 2017. Factors affecting adoption and degree of adoption of soya bean in Ilu-Ababora Zone; Southwestern Ethiopia. Agricultural Science Research Journal, $7(1)$ : 15 -26.

[38] Shita A, Kumar N, and Singh S, 2018. Agricultural Technology Adoption and Its Determinants in Ethiopia: A Reviewed Paper. Asia Pacific Journal of Research I, 2347-4793.

[39] Tamru S, Minten B, Alemu D and Bachewe F, 2017. The rapid expansion of herbicide use in smallholder agriculture in Ethiopia: patterns, drivers, and implications. The European Journal of Development Research, 29(3), 628-647. https://doi.org/10.1057/ s41287-017-0076-5.

[40] Verbeek M, 2017. A guide to modern econometrics, 5th edition: Rotterdam School of Management, Erasmus University, Rotterdam.

[41] Wooldridge J.M, 2012. Introductory Econometrics: A Modern Approach, Fifth Edition., Michigan State University. 